\title{
Eye Injuries Caused by Fireworks
}

\begin{tabular}{|l|l|l|}
\hline J. & $\begin{array}{l}\text { Schappert- } \\
\text { Kimmijser }\end{array}$ \\
\hline
\end{tabular}

An enquiry into eye injuries caused by fireworks at the New Year 1958 festivities in the Hague (population 600,000) revealed 32 cases. Of these 24 were young persons under the age of 20, and the chief victims were boys between the ages of 10 and 14 .

11 of the 32 cases had received fairly serious injuries.

The result of this enquiry justifies a further investigation, covering larger areas of the country. With the help of the local health services and the eye specialists 24 Dutch towns will be covered by the enquiry in the next few weeks.

Ophthalmologica, Vol. 139, No. 6 (Juni I960)

:《] 